\title{
The Economic and Social Impact of the Adoption of Value- Added Tax in Saudi Arabia
}

\author{
ADEL BOGARI \\ Assistant Professor- College of Business Administration, Al-Baha University, KSA \\ Email: aabogari@bu.edu.sa
}

\begin{abstract}
The purpose of this study is to determine the economic and social effects of the adoption of value-added tax in the Kingdom of Saudi Arabia. To achieve this goal, a descriptive and an analytical approach was used. We examine a sample of (287) Saudi nationals working in the private and public sectors. Our methodology used the direct questionnaire delivery and receipt method. To process our data and test our research hypotheses, we used SPSS software. The results indicate that the implementation of the value-added tax increases the country's financial resources. However, such an initiative has a negative social impact and faces many challenges. Bearing on these results, we recommend the need to upgrade the quality of the implementation of the on value-added tax law through improving the efficiency and effectiveness of employees in the General Authority of Zakat \& Tax, and simplifying tax procedures until the positive effects on the economic and social side rebound. The researcher recommends the need to overcome economic challenges through the commitment of wholesalers and retailers to release tax invoices for all their dealings, and to organize their businesses through electronic invoices. The researcher recommends the need to overcome the social challenges that face the implementation of the value-added tax law, by promoting trust between the community and the General Authority of Zakat \& Tax and activating the role of the Zakat and Tax Authority in spreading awareness and tax culture to the community.
\end{abstract}

Keywords: Added Value, Tax, State Financial Resources, Purchasing Power, Inflation, Savings, Investment.

\section{Introduction}

Since January 1, 2018, the Kingdom of Saudi Arabia has started implementing the 5\% value-added tax, which is the lowest approved rate in the world. This measure is expected to have a positive impact on economic growth through an increase in GDP. According to the report of the International Monetary Fund (2019), economic reforms in the Kingdom have started to achieve positive results, and it is recommended to increase this percentage to match the ratios approved around the world. For example, the value-added tax rate reaches $25 \%$ in the European Union. The adoption of value-added tax is one of the mechanisms covered by the Kingdom's 2030 vision of reducing dependence on oil as a primary source and diversifying the sources of the economy to ensure financial balance, continuity of development, and sustainability of government services. The General Authority of Zakat \& Tax is responsible for managing and applying this tax in the Kingdom of Saudi Arabia.

The adoption of Value-Added Tax is one of the most controversial topics, not only among professionals in the field of law and tax, but also by economic sectors and broad segments of society interested in knowing the impact of value-added tax on consumers as well as knowing the various options available to consumers regarding goods subject to VAT. 


\section{Research Problem}

The research problem under study is the lack of sufficient studies on this topic, specifically on the impact of the adoption of value-added tax in the Kingdom of Saudi Arabia on the economy in general and on different social segments groups in the private and in the public sectors.

In light with the above assumptions, we formulate the following research question:

What is the economic and social impacts of introducing VAT in the Kingdom of Saudi Arabia?

In order to answer this question, we thought it useful to raise a set of sub-questions that would clarify the subject of our study.

Sub-questions:

- What is the concept of value-added tax?

- How big are the efforts made to adapt some of the value-added tax laws in the Kingdom of Saudi Arabia?

These questions are reformulated into the following research hypotheses:

\section{Research Hypotheses}

The first hypothesis (H1)

The adoption of VAT has a positive economic impact in the Kingdom of Saudi Arabia.

The second hypothesis (H2)

The adoption of VAT has a negative social impact in the Kingdom of Saudi Arabia.

The third hypothesis (H3)

VAT implementation faces challenges at more than one level in the Kingdom of Saudi Arabia.

\section{Research Objectives}

This study has a set of goals, which are as follows:

- $\quad$ Presenting and clarifying the importance of applying value-added tax,

- $\quad$ Presenting the challenges facing the implementation of VAT,

- Determine the impact of implementing value added tax on the growth of investment in the private and public sectors,

- Determine the impact of implementing value-added tax on consumer purchasing power,

- Determine the impact of implementing value-added tax on employment growth,

- Determine the challenges facing the implementation of value added tax in light of the growth of ecommerce and informal trade.

\section{Importance of the study}

Our rationale behind conducting this study is the changes that the Saudi economy is witnessing. Such changes need a great deal of income diversification. Among the options that the Kingdom pursued to reach 
this objective, we found the development of the tax system, specifically the value-added tax, in view of the importance of the tax as it is one of the main resources of the state's public treasury.

\section{Research Methodology}

To reach our research objectives and determine the impact of the adoption of value-added tax on the economic and social spheres, we will use accepted scientific approaches in economic and social sciences in general, and therefore we will rely on:

- The descriptive approach to develop our theoretical framework of taxation and highlight the importance of the state's involvement in economic activity.

- The inductive approach with the aim of studying and extrapolating some of the previous research and studies on taxation

- $\quad$ Statistical and standard methods.

- $\quad$ The tools used in the study are:

- Macroeconomic indicators, such as GDP, exports, taxes, trade balance, and social stability.

- A questionnaire

- $\quad$ Statistics and related packages,

- $\quad$ Laws and legislation on tax and trade.

Then, the rest of the paper is structured as follows. The second section presents the concept, characteristics and importance of adopting VAT. Section three reviews the economic and social effects of implementing value-added tax. Section four goes through previous research and experiences of some countries that adopted the value-added tax measure. In section five, we present our results and test our hypotheses.

\section{The Concept, Characteristics and Importance of Adopting Value Added Tax (VAT)}

\section{Definition of VAT}

In order to study the effects of value added tax, a proper definition of the concept of value added is necessary. Most definitions agree that added value is the difference between the sale value of goods and services (Output) and the cost of purchasing materials and other production costs, including the percentage of depreciation of assets that go into manufacturing goods and services (Input).

VAT can be defined as a tax on consumption or spending in all its forms and imposed on the value added at each stage of production. In theory, it can be considered a tax on public spending in all its forms. It is a tax borne by the final consumer of the good or the last beneficiary of the service. Therefore, it is considered a transfer tax. To understand the nature of this tax, it should be noted that the goods go through different and multiple stages since they were raw materials (primary commodities) until they reach the consumer as finished goods. Through these different production stages each person has added-value, whether during the production stage or during the retailing stage, known as production cost factors (materials, salaries, wages, rents, profit margins, etc.). At this level, the tax is imposed on this added value or on this difference between the production value at the beginning of the stage and its value at the end of the stage.

\section{Characteristics of VAT}

\section{The relative $5 \%$ tax}

The Saudi law sets VAT rate at $5 \%$ of the value of goods and services. It should be noted that this percentage is the lowest in the world. Australia (10\%), Egypt (13\%), Turkey (18\%), Germany (19\%), Morocco (20\%), France (20\%), Italy (22\%). 


\section{Indirect Tax}

As the business does not bear the VAT burden, this tax is considered an indirect tax borne by the end consumer. In order to clarify the method of discounting and the end-consumer bearing the tax, we will explain the procedure in the following example (Figure.1):

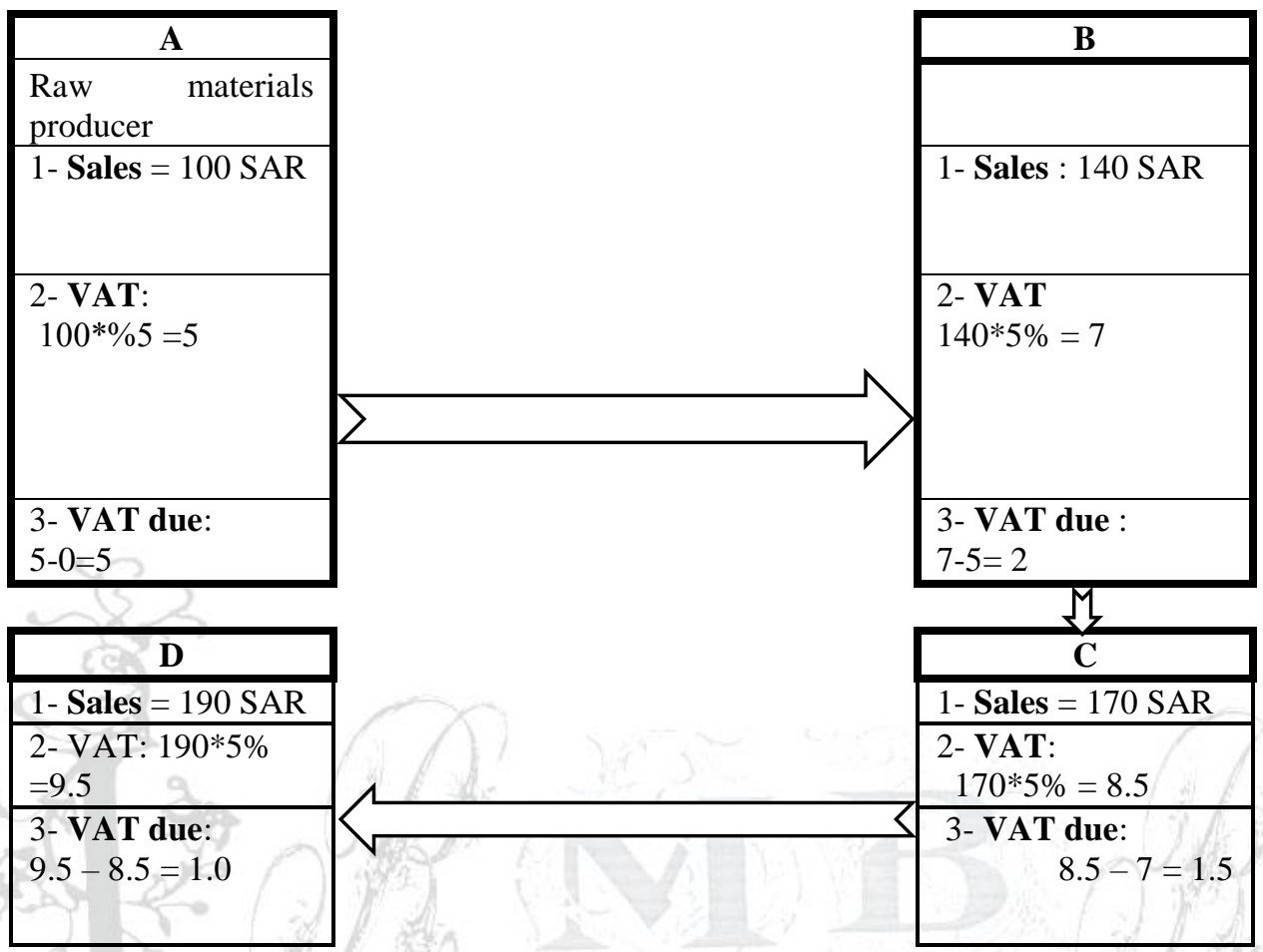

Figure 1. Method of discounting indirect tax

Source: Ravindra , jripathi, amblika sinha, sweta agarwal " the effect of value added taxes on the Indian society " journal of accounting and taxation, VOL 3 (2), 2011. P.32-39.

Thus, the value-added tax has become as follows:

$2+5+1.5+1=9.5=5 \% * 190$

\section{Periodic Tax (Monthly, ....)}

Where the taxpayer is forced to pay to the relevant tax authority (The General Authority of Zakat \& Tax) with periodic statements attached to the specified dates.

\section{A Value Tax}

It is imposed on the value of the good or service, regardless of the type of commodity, as a specific percentage of the value of all goods and services.

\section{Regional Tax}

The value-added tax applies to local products as well as to goods imported from abroad and sold domestically. As for exported goods, they are not subject to this tax. 


\section{Added tax not considered a cost component.}

The registered operator may not consider the tax paid on their inputs as cost elements because they can deduce this tax from the tax due on their sales.

\section{Tax Collection}

\section{Collection Method}

Tax is not collected once or during a specific period, but it is collected at every production and sale stages and on the added part in each stage and is not imposed on the value for which a tax was previously paid. Example: imagine that the store is selling and shipping 20 of its 100 TVs to a customer in Egypt. We want to know which amount of VAT is due to government.

Table No 1

\begin{tabular}{|l|l|l|l|l|l|}
\hline \multicolumn{1}{|c|}{ Transactions } & $\begin{array}{c}\text { Unit price } \\
\text { before tax }\end{array}$ & Tax on each unit & $\begin{array}{c}\text { Units } \\
\text { sold }\end{array}$ & Total tax & $\begin{array}{c}\text { Tax } \\
\text { label }\end{array}$ \\
\hline $\begin{array}{l}\text { 1- Buying goods from } \\
\text { factory }\end{array}$ & $1,000 \mathrm{R}$ & $50 \mathrm{R}=\% 5 * 1,000$ & 100 & $50 * 100 \mathrm{TV}=5,000$ & Inputs \\
\hline $\begin{array}{l}\text { 2- selling goods to a } \\
\text { consumer in Saudi } \\
\text { Arabia }\end{array}$ & $1,200 \mathrm{R}$ & $60 \mathrm{R}=\% 5 * 1,200$ & 80 & $60 * 80 \mathrm{TV}=4,800$ & Outputs \\
\hline $\begin{array}{l}\text { 3- Selling goods to a } \\
\text { consumer in Egypt }\end{array}$ & $1,200 \mathrm{R}$ & $0 \mathrm{R}=\% 0 * 1,200$ & 20 & $0 * 20 \mathrm{TVs}=0,000$ & Outputs \\
\hline
\end{tabular}

Source :Kingdom of Saudi Arabia VAT manuel $7^{\text {th }}$ Nov, 2017

https://www.vat.gov.sa/sites/default/files/2017-11-2/VAT_Manual_English_16_Nov.pdf

\section{How to record VAT in accounting books}

VAT is recorded in the journal according to the nature of the account. In case of purchases, we debit purchase and VAT and credit Cash or bank or name of creditor account or account payable. In case of sales, we debit cash or bank or account receivable and credit sales and VAT. To illustrate this, we provide the following example:

Example $\mathrm{N}^{\circ}$. 1: Suppose that on 5/1/2018 Rayan purchased goods, on the account, for a value of 5250 riyals, including tax on the account from the computers company. This process is accounted for as follows:

Table No 2

\begin{tabular}{|c|lr|r|r|}
\hline \multicolumn{1}{|c|}{ Date } & \multicolumn{1}{|c|}{ Account } & Debit & Credit \\
\hline $5 / 1 / 2018$ & Purchases & 5000 & \\
& VAT & & 250 & \\
& & To computers company & & 5250 \\
\hline
\end{tabular}

Suppose that on 5/1/2018 Rayan sold, in cash, a merchandise of 6850 riyals, inclusive of tax. This transaction should be recorded as follows: 
Table No 3

\begin{tabular}{|l|lr|r|r|}
\hline Date & Account & Debit & \multicolumn{1}{|l|}{ Credit } \\
\hline $5 / 1 / 2018$ & Cash & & 6850 & \\
& & Sales & & \\
& & VAT & & 6500 \\
& & & 325 \\
\hline
\end{tabular}

The question after these two transactions is: What is the tax amount payable to the General Authority of Zakat \& Tax?

Answer: $325-250=75$

\section{VAT goals}

VAT goals revolve around financial, economic, social, and finally administrative goals.

- The financial goals are to increase public revenues, or to provide the largest possible amount of revenue to the state's treasury.

- As for the economic goals, it is to finance the development of projects and different economic programs, and to dismantle financial bottlenecks, or contingencies faced by the state, therefore States need huge financial resources. This forces them to search for resources to increase their revenues.

- The social goals are to reach tax justice by allowing some exemptions for essential and basic commodities for some income earners (Kaisa, 2018).

- Finally, the administrative goals are to simplify tax legislation so that it can be easily accepted by its payers and also contribute to improving tax performance. These goals have emerged and been consistent with the tax reform policies that have been introduced in most countries (Al-Abdali et.al, 2019).

\section{The Economic and Social Effects of Implementing Value-Added Tax}

\section{The Effect of (VAT) on Investment}

The application of value-added tax may have a positive impact on stimulating investment and production for two reasons (the discount and liquidity principle):

a. The taxation principle gives the investor the right to recover the value of the tax that they previously incurred on the services acquired by them under the tax-exempt economy, whether it is fixed assets or current expenses (Atwi, 2004: Al-Madhidi 2018)

The principle of tax deduction has a positive impact on investment and results from the non-increase in the cost of investment equivalent to the value of the tax imposed, thanks to the possibility of recovering the amounts paid as a tax on the purchase of equipment and materials needed to manufacture the commodity or to perform the service subject to VAT (Camel, 1992: Jalata, 2011).

b. The second factor bears on the liquidity factor that results from keeping the funds collected until the due date.

\section{The impact of (VAT) on international competition}

Exemption of exports from value-added tax with the right to deduction provides the value-added tax with its complete neutrality with regard to external and internal trade, and thus the choice and identification of markets is independent of the tax regime (Ugrieh, 2002: Sarmento, 2016). 
Seen from a different perspective, the adoption of value-added tax encourages exports because exported goods are exempt from tax. In addition to the advantage of tax exemption in the final stage, it is possible to recover all the tax paid in the previous exporting stages, and therefore the value-added tax supports the competitiveness of domestic products in foreign markets (Othman, 2000: Al-Madhidi, 2018).

\section{The Effect of (VAT) on prices, Inflation, and Purchasing Power}

\section{The Effect of VAT on Prices}

The dependence of most countries around the world on value-added tax initially resulted in an increase in prices, but the wave of price increases was adjusted in light of the climate of competition on which the free economy is based. This amounts to determining demand volume, casting the tax burden upon the buyer and seller together, in contrast to the principle that the indirect tax is fully born by the consumer. The tax burden is transferred from the importer or the producer and from the distribution circles to finally settle on the consumer. Thus, it is said that the tax should not affect production activity, yet it should be noted that although the consumer bears the full burden of the tax, distribution and recovery circles are indirectly involved in bearing the tax burden (Qutaish, 2002).

Economists think that the adoption of value-added tax will have three effects on prices:

1. Reducing prices of investments (capital goods - investment) and the institutions' stocks of goods, as a result of the deduction principle that is adopted by the value-added tax.

2. A slight decrease in prices when exporting, as the product (or the exported service) after deducing the tax originally collected on raw materials or investments and general burdens and in general the funds and services necessary for its production or importation. In addition, it is subject to zero tax rate, thanks to the tax deduction mechanism for tax-exempt exports with the right to deduction (Sharaf, 2008).

3. High consumer prices, if imposed on all goods and services consumed without exception or exemption, will cause inflation (Ritu, 2017).

\section{The effect of value-added tax on inflation}

One of the most important consequences of inflation is the rise in money supply compared to the quantity of goods and services offered in the market. To mend for this, the overall demand should be reduced due to its imbalance with the offered goods and services. In order to reach balance, economists believe that new laws should be enacted to impose modern taxes, or to raise the rates of previous taxes. This will ultimately lead to a low income and low demand for goods. Then, indirect taxes should not be considered to deal with this phenomenon, especially in developing countries that suffer from poor production due to the underdevelopment of their production system, as their tax regimes rely heavily on indirect taxes (Darwish, 2003: Oseni, 2017).

Hence, indirect taxes should be avoided and used as a means to remedy this phenomenon and raise its rate because this will inevitably lead to an increase in inflation after sensing the effect of tax on development.Tax is no longer a financial instrument only allocated to finance regular expenses under the traditional financial theory, whose target is maintaining internal and external security, but tax has become a means used by States to influence the different economic spheres and channel investments towards the achievement of social and economic development goals defined in the State's Economic policy (Al-Qaei, 2002: Eyisi, 2017).

There has been a great debate by economists about whether the application of value-added tax has inflationary effects. The outcome of that controversy is two-fold: The first trend sees that implementing value-added tax has no effect on the general level of prices, and that the simultaneous rise in prices is caused by the expansion of loan policies and increase in wages (Al-Morsy, 2004). However, the second 
trend sees that the adoption of value-added tax results in an increase in prices and an increase in the intensity of inflation in some countries. There are no final studies that clearly explain the effects of VAT on prices and inflation, due to several factors such as changes resulting from other influences such as a rise in wages or loan policy, consumption behavior or timing of the application of tax ..... etc. (Saleh, 2003: AlNaqash, 2003; Kalas, 2017).

\section{The Effect of VAT on Purchasing Power}

Most economic theories agree that an increase in commodity prices from the consumer point of view will reduce purchasing power and thus reduce demand, leading to lower sales and thus profits, and then less employment opportunities. Accordingly, economic theory assumes two scenarios:

- Real income may decrease through a decrease in nominal wages and payments of other production factors without any change in the general level of prices.

- Real income may decrease through an increase in price level while nominal wages and payments of other production factors remain constant or unaffected, depending on tax. In both cases, real household income may decrease depending on the amount of tax practiced.

\section{Previous Studies and Experiences of Some Countries Implementing Value-Added Tax}

\section{Previous Studies}

There are many studies that dealt with the effects of applying VAT:

Mohamed (1985) study dealt with the application of value-added tax in France. The study concluded that the old French legislation is not effective in the area of tax exemptions. The study indicated that modern French legislation has taken exemption measures for the purpose of achieving tax justice and among the most important of these exemptions is the exemption on both capital goods, necessary commodities, raw materials and semi-manufactured goods. Moreover, it extends exemption on some bodies and establishments such as non-profit bodies, government interests and institutions.

Ahmad (1999) study examined the wide application of value-added tax in many developed countries, which made many developing countries aware of it. The study also noted that value-added tax regimes in developing countries are very similar to those in developed countries.

Ahmed (2005) study aimed to determine the aspects surrounding the implementation of value-added tax, and to identify some of the problems that faced its application. It is noteworthy that value-added tax did not negatively affect revenue or prices if they were better applied. Of the most important results of the study: success in implementing value-added tax lies in the effectiveness of collection and increase in public revenues.

Abdel-Rahman, (2009) study aimed to identify the problems facing the implementation of value-added tax in order to reach appropriate solutions that would increase the efficiency of the tax system. The study concluded that incompatibility of tax laws with some accounting principles leads to several problems that result in unfairness of tax application.

Sultan (2010) study aimed to measure the role of value-added tax in achieving financial and social goals in the Syrian Arab Republic. The study concluded that value-added tax has a high financial return on the State's budget and also has a positive impact on investment. 
Naqd (2016) study aimed to show the efficiency of the accounting system in providing accounting information with qualitative characteristics that would enable the General Administration of Value Added Tax in Sudan to properly measure and determine the value-added tax on the taxpayer. One of the most important recommendations of the study is that the costly use of a good accounting information system enables the identification and measurement of value-added tax and reduces tax evasion.

Saleh (2018) shows the research problem studied by the author was the measurement and determination of the effectiveness of collecting value-added tax revenues and the effect of increasing value-added tax on the volume of public revenue in Sudan during the 2010 to 2015 period.

Alavuotunki et al, (2019) study aimed to determine the effect of VAT on government revenues and inequality between people. This study concluded that value-added tax led to an increase in total government revenues, and as a result increased spending in basic public services provided to poor families. On the other hand, value added tax has led to inequality between people with different income levels, and this tax has created differences in the savings rate.

\section{Experiences of Some Countries Implementing Value-Added Tax}

Several countries, such as Belgium, France, Portugal and the United Kingdom, studied data after adopting VAT. The results are as follows.

Belgium has applied a complex cumulative value-added tax that extends to all stages and has taken strict control measures. Prices have been frozen for the first three months after introducing this tax. This measure has led to a reduction in price increases. Revenues multiplied and people accepted a significant impact on prices in the future.

In France, there was a slight increase in the consumer price index. France conducted a study on valueadded tax and found that the differences in prices before and after the transformation reflect the correct changes in taxation. The Price Control Department made an effort to provide advice and set a table to calculate the gross profit margins to raise awareness and guide retailers and avoid price increases.

It should be noted that the Arab countries that have applied value-added tax, including Tunisia and Lebanon, expect that value-added tax will not have a noticeable impact on the overall price index for several reasons. Of these reasons, the introduction of the value-added tax came with an exemption policy for some products and sectors. According to many economists, the reason for lower inflation is the exemption of basic consumer goods from tax. Because if it is imposed on all goods and services without exception or exemption, it will inevitably cause inflation.

\section{The Results}

\section{Study Sample}

Our sample consists in targeting (300) Saudi nationals working in the private or public sector or others, of both gender.

\section{The Survey}

The researcher conducted a survey and administered questionnaires. The researcher relied on the direct delivery and receipt method. Of the administered questionnaires, 13 were rejected because of inappropriate responses. Therefore, the questionnaires that were valid and ready for statistical analysis are (287) questionnaires. 


\section{Data Sources}

The survey required:

a. Secondary sources: These are the data that could be obtained by looking at the relevant literature on the subject under study.

b. Primary sources: These are data from the field, which were collected by administering a questionnaire to the study sample to test our hypotheses.

\section{The Statistical Method}

The researcher used the Program for Social Sciences Statistical (SPSS) program. They relied on percentages, means and standard deviations to analyze the responses of our sample to the items of the questionnaire.

The researcher also used the T-test for a single sample and the probability level at (90\%), to determine the relationship between the dependent variable and independent variables. The significance level (alpha) is less than or equal to $5 \%(\alpha \geq 5.00)$. The percentages of occurrences of each item were found, as well as their mean and standard deviation.

\section{Questionnaire Internal Coherence and Reliability}

The researcher used the Cronbach's Alpha, which is a measure to check the internal coherence and reliability of questionnaires. The following table shows a high Alpha coefficient:

\begin{tabular}{|c|c|}
\hline \multicolumn{2}{|c|}{ Table No 4 } \\
\hline No of Items & Cronbach's Alpha \\
\hline$(28)$ & 0.862 \\
\hline
\end{tabular}

It is clear from the table above that Cronbach's Alpha is 0,862 , attesting to the consistency of the study questionnaire. It is worth noting that Cronbach's Alpha ranges between zero and one, closer to one indicates a high reliability and validity.

\section{Analysis of Questionnaire Data}

\section{Analysis of the items of dimension one: The Economic Impact of VAT Application}

Table No. 5: Mean and Standard Deviation of Economic Impact of Value Added Tax Application

\begin{tabular}{|c|c|c|c|c|c|}
\hline & Item & Mean & $\begin{array}{l}\text { Standard } \\
\text { deviation }\end{array}$ & Percent & Rank \\
\hline 1 & $\begin{array}{l}\text { The value-added tax contributes to increasing } \\
\text { the State's general revenue }\end{array}$ & 3.9443 & 1.29159 & 78.886 & 1 \\
\hline 2 & $\begin{array}{l}\text { The value-added tax provides additional } \\
\text { resources to the state budget that it avoids } \\
\text { debts }\end{array}$ & 3.7596 & 1.15633 & 75.192 & 4 \\
\hline 3 & $\begin{array}{l}\text { The adoption of value added tax leads to a rise } \\
\text { in the consumer price index }\end{array}$ & 3.7561 & 1.14801 & 75.122 & 5 \\
\hline 4 & $\begin{array}{l}\text { Adoption of value added tax in the local } \\
\text { market encourages entrepreneurs to think } \\
\text { about creating external markets (export is } \\
\text { exempt from tax) }\end{array}$ & 3.4564 & 2.14933 & 69.128 & 8 \\
\hline 5 & Accounting bookkeeping helps prepare the tax & 3.6934 & 1.14510 & 73.868 & 6 \\
\hline
\end{tabular}




\begin{tabular}{||l|l|r|r|r|r||}
\cline { 2 - 5 } & return accurately and easily & & & \\
\hline $\mathbf{6}$ & $\begin{array}{l}\text { The adoption of value-added tax leads to } \\
\text { inflation in the general level of prices }\end{array}$ & 3.6446 & 1.21147 & 72.892 & 7 \\
\hline $\mathbf{7}$ & $\begin{array}{l}\text { The adoption of VAT leads to a decrease in } \\
\text { real income per capita }\end{array}$ & 3.8676 & 1.26127 & 77.352 & 3 \\
\hline $\mathbf{8}$ & $\begin{array}{l}\text { The adoption of VAT leads to a decrease in } \\
\text { saving }\end{array}$ & 3.9443 & 1.23626 & 78.886 & 2 \\
\hline \multicolumn{2}{|c|}{ Total } & 3.75828 & 1.3249 & 75.1657 & \\
\hline
\end{tabular}

Tables (5-7 and 9) show the results on the importance of each item, and their rank as seen by respondents. It is clear from Table No. (5) the following:

The first item ranked important by our respondents is item 1, with $78 \%$ of responses, and a mean of (3.9443), greater than the hypothetical average identified by the researcher (3). The last ranked item by our respondents is item 8 , with $69 \%$ of responses and a mean (3.4564), greater than the hypothetical average identified by the researcher. As for the economic impact of applying the tax on value Added in the Kingdom of Saudi Arabia, it is found to be significant.

Table No 6

\begin{tabular}{|c|c|c|c|c|c||}
\hline \multicolumn{1}{|c|}{ Dimension } & Mean & $\begin{array}{c}\text { Standard } \\
\text { deviation }\end{array}$ & t-Student & $\begin{array}{c}\text { Significance } \\
\text { level }\end{array}$ \\
\hline 1 & $\begin{array}{l}\text { The economic effect of VAT } \\
\text { adoption in Saudi Arabia }\end{array}$ & 30.0662 & 6.38501 & 16.095 & 0.000 \\
\hline
\end{tabular}

In the table above, it is clear that the calculated t-value is greater than the tabular $(\mathrm{T})$, and this means that the study sample believes that the adoption of value-added tax has a positive impact on the economy in the Kingdom of Saudi Arabia.

\section{Analysis of the items of dimension 2: the social impact of applying value-added tax}

Table No. 7: The mean and standard deviation of the social impact of the implementation of value-added

\begin{tabular}{|c|c|c|c|c|c|}
\hline & Item & Mean & $\begin{array}{l}\text { Standard } \\
\text { deviation }\end{array}$ & Percent & Rank \\
\hline 1 & $\begin{array}{l}\text { I have a clear investment program and I } \\
\text { allocate a monthly budget for it }\end{array}$ & 3.1777 & 1.44592 & 63.55 & 6 \\
\hline 2 & $\begin{array}{l}\text { I invest every month of my remaining } \\
\text { monthly resources after purchasing all my } \\
\text { monthly consumption needs }\end{array}$ & 3.2091 & 1.28664 & 64.18 & 5 \\
\hline 3 & $\begin{array}{l}\text { I consume monthly what remains for me } \\
\text { after deducing the investment budget } \\
\text { allocated for each month }\end{array}$ & 2.8711 & 1.33305 & 57.42 & 8 \\
\hline 4 & $\begin{array}{l}\text { When making a purchase, I choose the } \\
\text { product that has the best relationship } \\
\text { (price, quality) regardless of whether it is } \\
\text { domestic or foreign }\end{array}$ & 3.6167 & 1.23730 & 72.33 & 1 \\
\hline 5 & $\begin{array}{l}\text { When prices of a specific product increase } \\
\text { and the increase exceeds my budget level, } \\
\text { I buy the product and decrease the usual } \\
\text { purchase amount. }\end{array}$ & 3.2404 & 1.31746 & 55.19 & 9 \\
\hline 6 & When prices rise and exceed my budget, I & 2.4913 & 1.41881 & 70.17 & 2 \\
\hline
\end{tabular}




\begin{tabular}{|c|c|c|c|c|c|}
\hline & $\begin{array}{l}\text { resort to debt and maintain the same } \\
\text { standard of living }\end{array}$ & & & & \\
\hline 7 & $\begin{array}{l}\text { The adoption of value-added tax will entail } \\
\text { the recruitment of competencies in order to } \\
\text { prepare the tax declaration accurately and } \\
\text { transparently }\end{array}$ & 3.1538 & 1.21284 & 63.07 & 7 \\
\hline 8 & $\begin{array}{l}\text { The adoption of value-added tax leads to } \\
\text { rationalization of consumption }\end{array}$ & 3.2892 & 1.27235 & 65.78 & 4 \\
\hline 9 & $\begin{array}{l}\text { The adoption of value-added tax burdens } \\
\text { the budget of the socially vulnerable } \\
\text { groups }\end{array}$ & 3.8188 & 1.22414 & 43.62 & 10 \\
\hline 10 & $\begin{array}{l}\text { Adoption of value-added tax increases } \\
\text { state spending in public services }\end{array}$ & 3.4808 & 2.11029 & 69.61 & 3 \\
\hline \multicolumn{2}{|r|}{ Total } & 3.23489 & 1.3858 & 64.6978 & \\
\hline
\end{tabular}

In table 7,72\% of our respondents ranked first item 4 with a mean of (3.6167), greater than the hypothetical average that the researcher identified. The last ranked item by $43 \%$ of our respondents is item 9, with a mean (3.8188), greater than the hypothetical average identified by researcher. As for the social impact of applying VAT in Saudi Arabia, the results are significant as shown in the table below.

Table No 8

\begin{tabular}{|c|c|c|c|c|c|}
\hline \hline & Dimension & Mean & $\begin{array}{c}\text { Standard } \\
\text { deviation }\end{array}$ & t-Student & $\begin{array}{c}\text { Significance } \\
\text { level }\end{array}$ \\
\hline 1 & Social impact of VAT adoption & 32.3392 & 6.7158 & 5.890 & 0.000 \\
\hline
\end{tabular}

From the above table, it is clear that the calculated value of $t$-student is greater than the tabulated (t). This means that the study sample believes that the adoption of value-added tax has a negative social impact in the Kingdom of Saudi Arabia.

\section{Analysis of the items of dimension 3: the challenges of adopting VAT}

Table No. 9: The mean and standard deviation of the challenges of implementing VAT

\begin{tabular}{||l|l|c|c|c|c||}
\hline \multicolumn{1}{|c|}{ Items } & Mean & $\begin{array}{l}\text { Standard } \\
\text { deviation }\end{array}$ & Percent & Rank \\
\hline $\mathbf{1}$ & $\begin{array}{l}\text { Maintaining accounting records is a catalyst to } \\
\text { avoid double taxation }\end{array}$ & 3.4843 & 1.24271 & 69.7 & 8 \\
\hline $\mathbf{2}$ & $\begin{array}{l}\text { VAT is a catalyst for maintaining accounting } \\
\text { records }\end{array}$ & 3.5261 & 1.11812 & 70.5 & 7 \\
\hline $\mathbf{3}$ & $\begin{array}{l}\text { The adoption of VAT creates additional difficulties } \\
\text { for small enterprises }\end{array}$ & 3.5854 & 1.21997 & 71.7 & 6 \\
\hline $\mathbf{4}$ & $\begin{array}{l}\text { The adoption of value-added tax increases the need } \\
\text { for consulting tax authority and the methods for } \\
\text { dealing with it }\end{array}$ & 3.6376 & 1.07142 & 72.8 & 2 \\
\hline $\mathbf{5}$ & $\begin{array}{l}\text { The adoption of value-added tax leads to the need } \\
\text { for the government to take a package of measures } \\
\text { and actions to protect the poor and middle social } \\
\text { groups }\end{array}$ & 3.7631 & 1.24862 & 75.3 & 1 \\
\hline $\mathbf{6}$ & $\begin{array}{l}\text { The adoption of value-added tax leads to the } \\
\text { growth of informal trade, which is not subject to } \\
\text { tax }\end{array}$ & 3.5923 & 1.19630 & 71.8 & 5 \\
\hline $\mathbf{7}$ & \begin{tabular}{l} 
The adoption of value-added tax leads to the \\
\hline
\end{tabular} & 3.5958 & 1.14525 & 71.9 & 4 \\
\hline
\end{tabular}




\begin{tabular}{|c|c|c|c|c|c|}
\hline & growth of e-commerce & & & & \\
\hline 8 & $\begin{array}{l}\text { The adoption of value-added tax leads to } \\
\text { competition in the prices of similar products }\end{array}$ & 3.4355 & 1.15049 & 68.7 & 9 \\
\hline 9 & $\begin{array}{l}\text { The VAT system includes a precise definition of } \\
\text { exemptions and benefits }\end{array}$ & 3.3136 & 1.15537 & 66.3 & 10 \\
\hline 10 & $\begin{array}{l}\text { The VAT system includes precise measures to } \\
\text { track down tax evasion }\end{array}$ & 3.4843 & 1.20438 & 72.6 & 3 \\
\hline & Total & 3.5564 & 1.1752 & 3.5564 & \\
\hline
\end{tabular}

Table No 10

\begin{tabular}{||c|c|c|c|c|c|}
\hline \hline & \multicolumn{1}{|c|}{ Dimension } & Mean & $\begin{array}{c}\text { Standard } \\
\text { deviation }\end{array}$ & t-Student & $\begin{array}{c}\text { Significance } \\
\text { level }\end{array}$ \\
\hline 1 & VAT challenges & 35.5645 & 7.5744 & 12.445 & 0.000 \\
\hline
\end{tabular}

In the above tables $(9 \& 10)$, it is clear that the calculated $(t)$ is greater than the tabulated $(t)$. This means that the study sample believes that the application of value-added tax faces challenges on more than one level in the Kingdom of Saudi Arabia.

As for the rank of items by our respondents, item 5 was ranked first by $75 \%$ of respondents, with a mean of (3.7631), greater than the hypothetical average that the researcher identified. The last ranked item by $66 \%$ of our respondents is item 9, with a mean (3.3136), greater than the hypothetical average identified by researcher. As for the challenges facing VAT adoption in the Kingdom of Saudi Arabia, the results are significant as shown in the table above. It is clear that the calculated value of t-student is greater than the tabulated ( $\mathrm{t}$ ). This means that the study sample believes that VAT adoption faces many challenges in Saudi Arabia.

\section{Conclusions and Recommendations}

\section{Results}

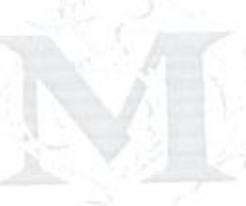

The researcher reached a set of results, the most important of which are:

1. There is a strong and statistically significant correlation between VAT application and economic variables such as investment, consumption, inflation, purchasing power and the trade balance.

2. There is a strong and statistically significant correlation between VAT application and social variables, mainly represented by prices, purchasing power and social welfare.

3. There is a strong and statistically significant correlation between VAT implementation and the economic and social challenges facing the Kingdom of Saudi Arabia.

\section{Recommendations}

1. The researcher recommends the need to develop the quality of VAT implementation, by improving the efficiency and effectiveness of employees in the Saudi Zakat and Tax Authority, their continuous training, the use of information technology by this authority, and standardizing and simplifying tax procedures so that positive effects on the economic and social spheres can be reached.

2. Researcher recommends the need to overcome the economic challenges facing VAT implementation, through the commitment of wholesalers and retailers to release tax invoices of all their transactions, establish tax rules for domestic and international e-commerce, and regulate business through electronic invoices.

3. Researcher recommends the need to overcome social challenges facing VAT application, by promoting trust between the community and the General Authority of Zakat \& Tax and activating the role of the 
General Authority of Zakat \& Tax in spreading awareness and taxation culture to the community, improving the level of wages for community members, and the obligation of registrants to keep regular books and accounts, activating the role of the social interest through training registrars on how to apply the provisions of the value-added tax law and its executive regulations, and training registrars on dealing with the Saudi Zakat and Tax Authority through the tax services portal.

\section{Acknowledgments}

The author acknowledges the financial support of the Deanship of Scientific Research at AlBaha

University, Kingdom of Saudi Arabia. This article, which is part of the research Project No. P16/1440, is developed within the framework of research Programs of AlBaha University.

\section{References}

Ahmed Sanaa Ibrahim Al-Ahmad (2005). Value Added Tax in Sudan - Mechanism for Implementation and Economic Effects. University of Khartoum - Khartoum

Alavuotunki Kaisa et al., (2018). The Effects of the Value-Added Tax on Revenue and equality. The Journal of Development Studies, pp.1-19.

Al-Madadi, Naseer Mashaan, (2018). The Impact of Diversity in Public Revenues on the Public Budget in Jordan, Unpublished Master Thesis, University of Al-Bayt, Faculty of Economics and Administrative Sciences, Jordan.

Al-Mursi, Mr. Hijazi,(2004). Income, Wealth and Expenditure Taxes in Lebanon with Presentation and Analysis of Value Added Tax, University House, Beirut, Lebanon.

Al-Naqash, Ghazi Abdel-Razzaq, (2003). Public Finance - Analysis of the Basics of Financial Economics, Dar Al-Awael Publishing, Amman, Jordan.

Al-Qaei, Fadi Moyes, (2002). The Value Added Tax, Supplement to Law $N^{\circ} 379$ in accordance with the implementing decrees, Dar Al-Nahar, Beirut, Lebanon, translated by Kamel Majeed Saada.

Atwi, Fawzi, (2003). Public Finance: Tax Regulations and the State Budget, Al-Halabi Human Rights Publications, Beirut, Lebanon.

Darwish, Mohamed Kamel, (2003). Value-added tax, an essential step to keep pace with the global economy, Dar Beirut, Beirut, Lebanon.

Eyisi Adanma Sabina, et al, (2017). Comparative Analysis of the VAT System of Developed and Developing Economies (UK and Nigeria). Research Journal of Finance and Accounting,Vol.8, $\mathrm{N}^{\circ}$.22,pp.66-72.

Al-Abdali Iman Mudhi, Rawiya Rida Obaid and Talal Ibrahim Sajini, (2019). The impact of the application of value-added tax on the revenues of the public budget in the Kingdom of Saudi Arabia, The Arab Journal of Literature and Humanities - Issue 6. https://www.vat.gov.sa/sites/default/files/2017-112/VAT_Manual_English_16_Nov.pdf

Jalata, D. M, (2014). The Role of Value Added Tax on Economic Growth of Ethiopia. research journal, Vol.1, pp.156-161.

Kalas, Branimir, (2017). The role of value added tax in the economy of Serbia. Scientific review article, 63(2),p.69- 78.

Naqd Fatima Ahmed, (2016). Accounting Information System and its Role in Measuring Value Added Tax, A Field Study on the General Administration of Value Added Tax - Sudan Open University Khartoum.

Oseni, A., (2017). The Effects of Value Added Tax on Government's Revenue Generation Profile in Nigeria: A Conceptual Approach.

Othman, Sayed Abdel Aziz, (2000). Tax Systems - Entrance to Comparative Analysis, University House, Alexandria University, Egypt.

Qutaish, Abdel-Raouf, (2002). Value Added Tax Legislation and Implementation, Dar Al-Khulud, Beirut, Lebanon.

Ravindra, Jripathi , Amblika Sinha and Sweta Agarwal, (2011). The effect of value added taxes on the Indian society. Journal of accounting and taxation, Vol. 3 (2), pp.32-39. 
Ritu Sharma,(2017). An Analysis of the Impact of Value Added Tax (Vat) in Rajasthan, Journal of Commerce, Economics \& Computer Science, Vol.03, N. 03, July-Sept., pp. 44-48.

Saleh, Amin, (2003). Value Added Tax between Theory and Practice, Part One and Part Two, Sader Publishers Library, Beirut, Lebanon.

Sarmento, Joaquim, (2016). The determinants of value added tax mrevenues in the europen union, The europen. Journal of management mstudies, 21(2), pp.79-99.

Sharaf, Samir, (2008). Monetary and Financial Economics, October, University Publications.

Sultan Muhammad Hamid, (2010). The role of value-added tax in tax reform in Syria, University of Aleppo - Aleppo.

Ugria, George, (2002). Value Added Tax - Supplement to Lebanese Law and Applied Tax Decrees, translated by HE Kamel Majeed, University Foundation for Studies, Publishing and Distribution, Beirut, Lebanon.
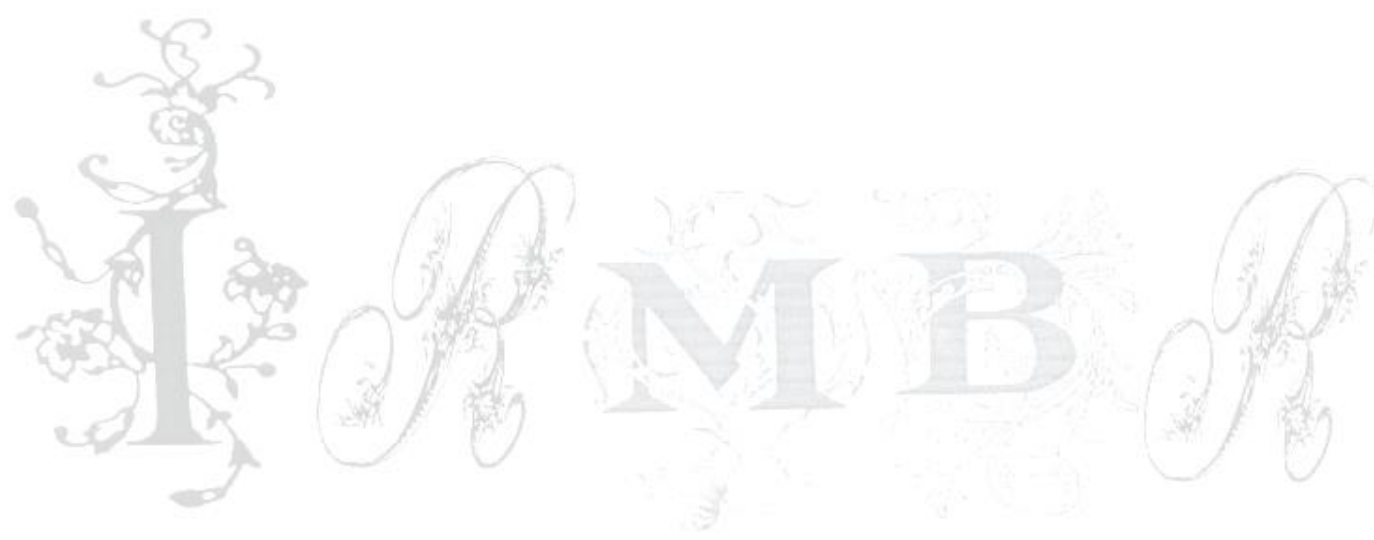